Jurnal Bisnis dan Manajemen, Volume 20, No. 2, September 2019, p. 145-174

\title{
EFFICIENCY AND PRODUCTIVITY ANALYSIS OF INDONESIAN REGIONAL DEVELOPMENT BANKS: MULTI-STAGE DEA APPROACH AND MALMQUIST PRODUCTIVITY INDEX
}

\author{
Efa Yonnedi ${ }^{1}$, Abdul Rahman Panjaitan ${ }^{2}$ \\ 1,2 Universitas Andalas, Indonesia
}

\begin{abstract}
This research is intended to empirically examine the efficiency and productivity change of 26 regional development banks (BPDs) in Indonesia in 2011-2016 using a non-parametric approach of data envelopment analysis (DEA). This research was started by determining input and output variables based on three approaches, i.e., intermediation, operation, and the asset approach. The Multi-stage DEA was adopted to generate the efficiency score, and the inputorientated variable return to scale (VRS) assumption is specified in data analysis. The Malmquist Productivity Index (MPI) was used to measure the total factor productivity change indicating the improvement or deterioration of performance of BPDs over time. The multi-stage DEA result shows a significant difference in the number of efficient BPDs using the three approaches. MPI shows that the highest productivity increase was in the asset approach of $84.0 \%$, supported by the increase in efficiency change and technological change. While in intermediation and operation approach, the increase was only $44.0 \%$ and $36.0 \%$, depending on the increase in efficiency change and scale efficiency change. This research suggests that BPDs need to invest more in technology to increase firm efficiency.
\end{abstract}

Keywords: data envelopment analysis (DEA), efficiency, Indonesian regional development bank (IRDB), malmquist productivity index (MPI)

\section{ANALISIS EFISIENSI DAN PRODUKTIVITAS BPD SE-INDONESIA: PENDEKATAN MULTI-STAGE DEA DAN MALMQUIST PRODUCTIVITY INDEX} \begin{abstract}
ABSTRAK
Tujuan penelitian ini adalah untuk menguji secara empiris efisiensi dan perubahan produktivitas 26 Bank Pembangunan Daerah (BPD) di Indonesia selama periode 2011-2016 dengan pendekatan non parametrik Data Envelopment Analysis (DEA). Penelitian dimulai dengan menentukan variabel input dan output berdasarkan tiga pendekatan, yaitu intermediasi, operasi dan aset. Multi-stage DEA diadopsi untuk mengetahui nilai efisiensi BPD, asumsi Input-orientated variable return to scale (VRS) ditentukan dalam menganalisis data. Malmquist Productivity Index (MPI) digunakan untuk mengukur total factor productivity change yang menunjukkan peningkatan atau penurunan kinerja setiap tahunnya. Hasil Multi-stage DEA menunjukkan perbedaan yang signifikan pada jumlah BPD yang efisien dari ketiga pendekatan. MPI menunjukkan peningkatan produktivitas 84,0\% BPD melalui pendekatan aset didukung dengan peningkatan efficiency change dan technological change, sementara peningkatan 44,0\% dan 36,0\% BPD dari pendekatan intermediasi dan operasi berturut-turut tergantung pada peningkatan efficiency change dan scale efficiency change. Penelitian ini memberi justifikasi kepada BPD untuk investasi pada teknologi untuk meningkatkan efisiensi perusahaan.
\end{abstract}

Kata-kata kunci: Efisiensi, Data envelopment analysis (DEA), Bank, Malmquist productivity index (MPI)

Korespondensi: Efa Yonnedi, Ph.D., MPPM., Ak., CA. Faculty of Economics Universitas Andalas. Jln. Universitas Andalas, Limau Manis, Pauh, Limau Manis, Pauh, Kota Padang, Sumatera Barat 25163. Email: efayonnedi@eb.unand.ac.id.

Submitted: July 2019, Accepted: September 2019, Published: September 2019 
Jurnal Bisnis dan Manajemen, Volume 20, No. 2, September 2019, p. 145-174

\section{INTRODUCTION}

The Indonesian Regional Development Banks (IRDBs) play a strategic role in regional economic development. The ownership structure of the IRDBs is concentrated on the regional or local government in Indonesia. The IRDBs have a size and business scale, which may reduce poverty, increase access to the financing, and develop the real sector in the rural areas. According to the Indonesian Banking Statistics (2016), IRDBs were in the fifth position in terms of asset, third-party fund, and the credit provided - after Bank Rakyat Indonesia, Bank Mandiri, Bank Central Asia, and Bank Negara Indonesia. IRDBs are believed to be comparable with the large banks, and they can take part in the national development by developing the rural areas of Indonesia. The failure in IRDBs will have a systemic impact on the regional economy.

In 2016, there were only 26 BPDs throughout Indonesia. Currently, there are 27 IRDBs after the formation of Bank Banten in Banten province. The primary financial indicators of IRDB, namely, compound annual growth rate (CAGR) of asset, third-party fund, and the credit provided, generally had consistent growth in 2011-2016, as shown in table 1 .

The improvement in primary financial indicators does not mean that the competitiveness of IRDBs also improves. Several studies show that the market share of IRDBs declined in each area. It shows that the competitiveness of IRDBs is assumed to be low, so there is a chance to examine the efficiency and productivity of IRDBs to gain the empirical evidence and the steps needed to improve them. Low competitiveness is often associated with limited capital and weak corporate governance. The test of the efficiency of IRDBs using asset, operational, and intermediation approach was not commonly conducted in Indonesia (Wijatmoko, 2011). The previous research mainly focused on the financial ratios and financial conditions of IRDBs covering risk aspects, Good Corporate Governance (GCG), capital, and rentability. Bauer et al. (1998) stated that in measuring the company's performance, including banks, the efficiency analysis is much better than the financial ratio analysis such as using Return on Assets (ROA) or Operating Expense Ratio (OER).

This paper aims to empirically test the efficiency level and productivity change of IRDBs throughout Indonesia in 2011-2016 by using the nonparametric approach of Data Envelopment Analysis (DEA). Malmquist Productivity Index (MPI) was used to measure the source of a total change of productivity factor. The result of this study is expected to become useful input for IRDBs and regulators in transforming and developing the business of IRDBs. 
Jurnal Bisnis dan Manajemen, Volume 20, No. 2, September 2019, p. 145-174

Table 1. Total Assets, Third Party Funds, and Loans provided (in billion rupiahs)

\begin{tabular}{lccccccc}
\hline & Dec-11 & Dec-12 & Dec-13 & Dec-14 & Dec-15 & Dec-16 & CAGR \\
\hline Total Assets & 307,80 & 371,81 & 390,17 & 451,86 & 486,35 & 529,19 & \\
Growth & N/A & $20,8 \%$ & $4,9 \%$ & $15,8 \%$ & $7,6 \%$ & $8,8 \%$ & $11,6 \%$ \\
Third party funds & 232,60 & 284,01 & 282,99 & 333,2 & 355,53 & 372,60 & \\
Growth & N/A & $22,1 \%$ & $-0,4 \%$ & $17,7 \%$ & $6,7 \%$ & $4,8 \%$ & $10,2 \%$ \\
Loans provided & 170,99 & 219,71 & 255,88 & 294,60 & 311,24 & 334,23 & \\
Growth & N/A & $28,5 \%$ & $16,5 \%$ & $15,1 \%$ & $5,6 \%$ & $7,4 \%$ & $14,6 \%$ \\
\hline
\end{tabular}

Source: Bank Indonesia (2016)

\section{LITERATURE REVIEW}

The measurement of bank efficiency is practically measured by the ability of the bank to generate operational income by using operating expenses. This ratio is often called as Operating Expense Ratio or OER. The lower the OER is, the efficient a bank becomes, conversely. This idea is in line with Farrell (1957), stating that firm efficiency relates to how it can generate a maximum output using the input used. Efficiency is not always about minimizing the cost, but it can also mean the management of the inputoutput relationship. Farrell (1957) proposed that firm efficiency consists of two components, namely technical efficiency, and allocative efficiency. Technical efficiency reflects the ability of a company to gain maximum results by using particular input. While allocative efficiency reflects the ability of a company to use input in an optimum proportion by considering each input's price. These two measurements are used to measure total economic efficiency.

EFFICIENCY AND PRODUCTIVITY ANALYSIS OF INDONESIAN REGIONAL DEVELOPMENT BANKS: MULTI-STAGE DEA APPROACH AND MALMQUIST PRODUCTIVITY INDEX

(Efa Yonnedi, Abdul Rahman Panjaitan)
Farrell (1957) further illustrated his idea by using a simple example, as shown in figure 1. Figure 1 shows that a company uses two inputs ( $\mathrm{x} 1$ and $\mathrm{x} 2$ ) to generate a single output (y), assuming a Constant Return to Scale (CRS). The knowledge about the isoquant unit of the fully efficient company is represented by $\mathrm{SS}^{\prime}$ in figure 1, ensuring the measurement of technical efficiency. If a company uses particular input as determined by $\mathrm{P}$ point to generate an output of a certain unit, the technical inefficiency of this firm is represented by QP distance, i.e., the number which can be used by all inputs proportionally without reducing the output. It is usually stated in percentage using the ratio of $\mathrm{QP} / 0 \mathrm{P}$, representing the percentage where all input can be minimized. Technical Efficiency (TE) of a firm is often measured by the ratio of TEI $=0 \mathrm{Q} / 0 \mathrm{P}$, which equals to 1 - $\mathrm{QP} / 0 \mathrm{P}$. It can be shown by the value between zero and one, showing the indicator of firm technical efficiency level. The value of one shows that the firm is technically fully efficient. As 
Jurnal Bisnis dan Manajemen, Volume 20, No. 2, September 2019, p. 145-174

an example, the $\mathrm{Q}$ point is technically efficient because it is located on efficient isoquant.

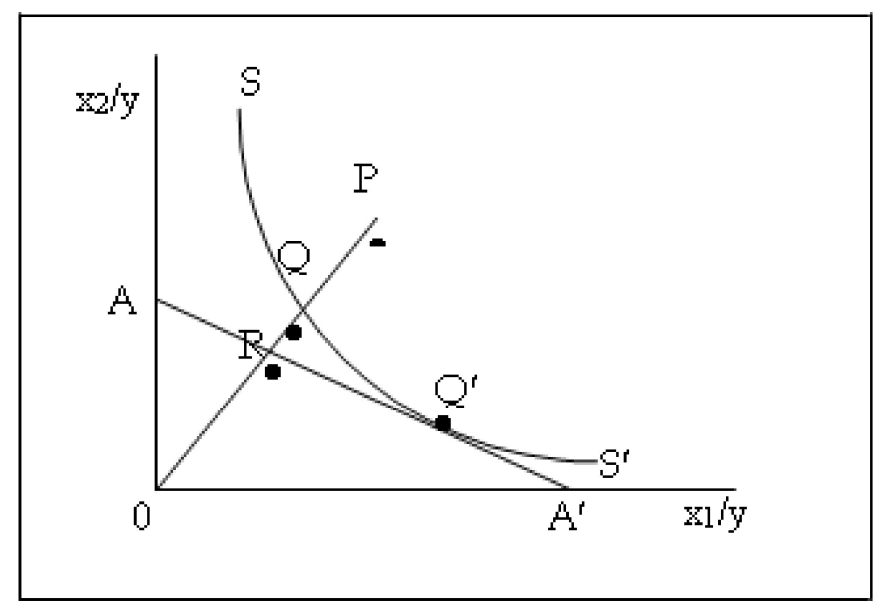

Figure 1. Technical and Allocative Efficiency

Source: Farrell (1957)

If the ratio of input's price represented by the AA' line in figure 1 is known, the allocative efficiency can also be calculated. Allocative efficiency of a firm operating on $\mathrm{P}$ is defined as ratio $\mathrm{AEI}=0 \mathrm{R} / 0 \mathrm{Q}$ because the distance of RQ shows the reduction of production expense, which will happen if the production is on Q' point (efficient in terms of allocation and technical aspect). While if on Q point is technically efficient but inefficient in terms of allocation. The total economic efficiency (EE) is defined as the ratio of EEI $=0 \mathrm{R} / 0$, where the distance of RP can also mean the reduction of cost. The technical and allocative efficiency contribute to the total economic efficiency as follows:

$T E_{1} x A E_{I}=(0 Q / O P) x(0 R / O Q)=(0 R / O P)=E E_{I}$
The general measurement to measure the efficiency of financial institutions, including banks, consists of a parametric and non-parametric approach. According to Berger and Humphrey (1997), there are three methods that are commonly used in the parametric approach, namely, Stochastic Frontier Approach (SFA), Thick Frontier Approach (TFA), and Distribution-Free Approach (DFA). A stochastic frontier approach is an economical approach that defines the function of costs, profits, or production relationships among input, output, and environmental factors. Also, this approach enables the random error to presumably follow the standard symmetrical distribution. While TFA compares the average efficiency of a group of companies, and it does not predict the limitation aspect. DFA, on the other hand, uses the residual average of the functional cost estimation through panel data to determine measurement for frontier cost efficiency. This approach does not force a specific form of efficiency distribution but assumes that there is a core efficiency or average efficiency for a large company that is sustainable.

While in the non-parametric approach, there are two standard methods, namely Data Envelopment Analysis (DEA) and Free Disposal Hull (FDH). Data envelopment analysis is a mathematical programming approach to test the efficiency of the Decision-Making Unit (DMU) responsible for utilizing certain inputs to generate certain output. FDH is a generalization of the DEA 
Jurnal Bisnis dan Manajemen, Volume 20, No. 2, September 2019, p. 145-174

model, which does not need frontier estimation. Frontier estimation approach is a mathematical technique to define a company with the best practices, meaning that the performing firm is defined as a frontier. Bauer et.al. (1998) stated that in testing the performance of a firm, the approach analyzing frontier is more advanced than the method using a traditional financial ratio such as ROA or OER.

The recent survey conducted by Emrouznejad and Yang (2017) showed that the implementation of DEA in banking study was one of the top five fields in the last four decades (19782016), where the most journal articles were published in 2015 and 2016. DEA is a nonparametric method using a mathematical technique called linear programming (LP), which relates to the allocation and utilization of limited resources. Charnes, Cooper, and Rhodes (1978) firstly introduced DEA to measure the efficiency based on the concept of efficiency measurement proposed by Farrell (1957). Charnes, Cooper, and Rhodes (1978) developed an input-orientated model by assuming a constant return to scale (CRS). This model is known as CCR model. Subsequently, Banker, Charnes, and Cooper (1984) proposed a model assuming a variable return to scale (VRS). This model is also known as the BCC model.

DEA is a performance measurement tool to evaluate the relative efficiency of production and business unit in an organization. This entity is known as DMU in DEA. LP method solves a linear mathematical problem by resulting in an efficient virtual DMU and comparing it with the observed DMU in the analysis. The efficient virtual DMU is resulted from the best and most efficient DMU and becomes the standard for the observed DMU. From this analysis, the efficiency level of the observed DMU is known, and the slacks are identified and quantified. Slacks are the excess of input (or output), which can be reduced (or increased) to attain an efficient level after all inputs (or outputs) are reduced (or increased) proportionally to achieve the best practice. DEA identifies the "best practice" of DMU and gives a perfect score (fully efficient), and each variance of the "best practice" is considered inefficient. The inefficiency level depends on the score received by DMU. The efficiency score is based on several inputs and outputs as formulated as follows:

\section{Efficiency $=\underline{\text { Weighted sum of inputs }}$ \\ Weighted sum of outputs \\ DMU with score one is considered efficient,} and each score less than one is considered inefficient. According to Hadad et al. (2003), the DEA approach outperforms other methods because it does not need many data, so the needed data are fewer. Also, the assumption and sample size needed is fewer. However, the statistical conclusion cannot be drawn by using a non-parametric approach. The DEA approach is not included in random error, so the inefficiency score can only be used as a general inefficiency factor of DMU. The non-parametric REGIONAL DEVELOPMENT BANKS: MULTI-STAGE DEA EFFICIENCY AND PRODUCTIVITY ANALYSIS OF INDONESIAN REGIONAL DEVELOPM
APPROACH AND MALMQUIST PRODUCTIVITY INDEX (Efa Yonnedi, Abdul Rahman Panjaitan) 
Jurnal Bisnis dan Manajemen, Volume 20, No. 2, September 2019, p. 145-174

approach can be resulted to measure a general inefficiency level.

DEA has the advantage of being able to identify the unit, which will be used as a reference for helping to define the cause and solution of inefficiency, which is the primary thing in implementing managerial function. DEA uses many inputs and outputs with a few assumptions in the relationship between the input and output variables. Fetih and Pasiouras (2010) also stated that DEA does not require a complete specification in its function for showing the relationship between production and distribution under observation. Jemric and Vujcic (2002) stated that DEA has an advantage for not requiring early assumptions in the production function. Furthermore, DEA defines the best DMU practice by only using the observed data.

Meanwhile, the disadvantage of the DEA approach is the outlier, which affects the measurement of the total firm efficiency. Also, the frontier is highly sensitive in the extreme observation, and there is no random calculation. Thus, the frontier deviation is indicated as an inefficiency. Since DEA is a non-parametric approach, the test of the statistical hypothesis for DEA score is difficult, resulting in an inability to draw statistical decisions. DEA measures the relative efficiency between DMU under observation, not absolute efficiency.

As outlined previously, the CRS or CCR model was first introduced by Charnes, Cooper, and
Rhodes in 1978. The CRS model assumes that DMU will be compared with the entire sample of DMU in the research, where the internal and external conditions of DMU are assumed to be equal. CRS model was criticized because it is appropriate only for the condition where all DMUs are operated at an optimum scale. Even though DMU results in the same input as the output does, the internal and external conditions of DMU might be different so the DMU cannot be operated at an optimum scale.

According to Casu and Molyneux (2003), the CRS model is only appropriate to be used when all DMUs operate at an optimum scale. Several factors, such as imperfect competition and financial barriers result in DMU to operate less optimally. Thus, the CRS model implementation will result in inappropriate technical efficiency because it is not in line with the efficiency scale. The fundamental concept of this model is the constant result scale, meaning that adding one input to the operation will increase one output. If the input increases by $x$, the output will increase by $\mathrm{x}$ as well. The model of Charnes, Cooper, and Rhodes (1978) can determine technical efficiency as a whole or profit efficiency score for each DMU. Besides, Purwanto and Ferdinan (2006) also stated that CRS model is relatively more appropriate to be implemented in analyzing the performance of manufacturing companies.

Another model, called Variable Return to Scale (VRS) or BCC model, appeared as an 
Jurnal Bisnis dan Manajemen, Volume 20, No. 2, September 2019, p. 145-174

alternative to the CRS model. Banker, Charner, and Cooper first introduced the VRS model in 1984. This model assumes that adding more input by $\mathrm{x}$ will not increase output by $\mathrm{x}$. The output may be smaller or even larger. This model is used to test the efficiency of a service company, including a bank. According to Avkiran (1999), the VRS model is more appropriate for a large sample size. VRS portrays technical efficiency as a whole, consisting of pure technical efficiency and scale efficiency. Pure technical efficiency means the ability of the firm managers of DMU to maximize the available resources. Meanwhile, scale efficiency shows whether the DMU can operate at an appropriate production scale.

Wahidudin (2010) stated that the measurement of productivity change is a crucial aspect when considering the efficiency and performance of any financial institution. Banks and other financial institutions are expected to show productivity change as an innovation result of deregulation in the financial sector. Thus, technical efficiency and technological efficiency must be appropriately measured. Another aspect of DEA is Malmquist Productivity Index (MPI) mainly when focusing on the inefficiency aspect of a nonparametric method. Malmquist total factor productivity is based on the assumption of competitive behavior of the producer side regarding the input.
Total Factor Productivity (TFP) is the measurement of productivity involving production factors. Banks are said to be efficient if they are positioned as the frontiers. If they are found under the frontiers, they are technically inefficient. The shift in the production frontier is called technical change. TFP was initiated by Caves et al. (1982) who developed the Malmquist model from the scaling idea.

Nonetheless, Caves et al. (1982) did not calculate inefficiency. Fare (1992) tried to mix the ideas of Farrell (1957) in measuring efficiency and productivity. Subsequently, Caves et al. (1982) developed Malmquist Index of Productivity Change. The productivity of Malmquist measures productivity change of DMU. This research refers to the regional development banks in several periods. Some researchers defined MPI as a process where the production boundary shifts and the DMU are required to involve in productivity change (Caves et al., 1982). The important finding should cover two important aspects, namely, efficiency change and technological change. Therefore, TFP estimation must be obtained by explaining these two components.

Based on the DEA model, MPI is considered as the most popular index because it can handle much information related to the panel data and it has other useful features for researchers (Wahidudin, 2010). MPI appeared in the literature around 1980 as proposed by Nishimizu and Page (1982) in their 
Jurnal Bisnis dan Manajemen, Volume 20, No. 2, September 2019, p. 145-174

article regarding TFP growth. Their finding was based on the technological growth and technical change in Yugoslavia in 1965-1978. They explained productivity growth into two crucial elements by considering the change of time interval. For instance, technical change refers to the change of frontier level and efficiency change refers to the productivity change of individuals regarding the frontier. Also, MPI is based on the performance assumption that if the index is less than one, it worsens the condition. Moreover, if the index is more than one, it provides relevant improvement (Fare et al., 1994).

Chansarn (2008) utilized DEA by assuming a constant return to scale for analyzing the relative efficiency of commercial banks in Thailand in 2003 - 2006. The input and output variables were derived from the operation and the intermediation approach. Overall, the analysis showed that from the operation approach using the perspective of cost/revenue, the efficiency was stable and very high, or on average more than $90 \%$ per year. Nonetheless, from the intermediation approach, the efficiency was fair, and it fluctuated over the years or on average, $86 \%$ in 2003 and 2005 and $72 \%$ in 2004 and 2006.

Wijatmoko (2011) studied the efficiency of regional development banks in Indonesia in 20072009 using DEA approach. The intermediation approach was used to determine the input and output variables. Input variables consisted of general and administrative expenses, labor cost, and promotion expense, while output variables consisted of loan, third-party fund, and net profit. The result of that research showed that in 2007, eight banks (30.77\%) were fully efficient in their operations while the rest of 18 banks (69.23\%) were not at maximum efficiency level. In 2008, nine banks (34.62\%) were efficient in their operations, while the rest of 17 banks $(65.38 \%)$ were not at maximum efficiency level. Subsequently, in 2009, five banks (19.23\%) were fully efficient in their operations, while 21 of them $(80.77 \%)$ were not at maximum efficiency level. The cause of the inefficiency was dominated by input variables, namely the general and administrative expenses, labor cost, as well as promotion expense. Nonetheless, the percentage decreased from $83.08 \%$ to $68.92 \%$, and then to $63.64 \%$ (from 2007 to 2009).

In their study, Saeed et al. (2013) utilized a non-parametric DEA with two input and output orientations for calculating technical efficiency (TE), pure efficiency (PE), and scale efficiency (SE) of Islamic and conventional banks in Pakistan from 2007 to 2011. The results of their research showed that the TE of Islamic banks under the two measurements orienting to input and output was $83.9 \%$, was better than the public sector and foreign banks, but was weaker than private sector banks. PE with measurements orienting to input in Islamic banks was $93.2 \%$, which was better than public sector banks but worse than private and foreign banks. The measurement result orienting to the output of Islamic banks was $92.2 \%$, better than the 
Jurnal Bisnis dan Manajemen, Volume 20, No. 2, September 2019, p. 145-174

public sector and foreign banks but the performance of private sector banks was much better than the performance of Islamic banks. SE of Islamic banks under the two measurements orienting to input and output was $88.7 \%$ and $89.5 \%$. SE of Islamic banks with two measurements orienting to input and output was better than the public sector and foreign banks but worse than private sector banks in Pakistan.

Gunawan and Utiyati (2013) studied the efficiency of government-owned banks in Indonesia using the DEA approach. Input and output were defined using the intermediation approach consisting of the third-party fund, interest expense, and labor cost as the input and loan, interest income, and other operating income as the output. A variable return to scale (VRS) model with output orientation was used in his research. Gunawan and Utiyati (2013) found that four government-owned banks, namely BNI, BRI, BTN, and Bank Mandiri consistently reached the perfect efficiency score of $100 \%$.

Firdaus and Hosen (2013) tested the efficiency of Islamic banks in Indonesia using twostage DEA. Input and output variables were derived from the intermediation approach, namely thirdparty fund, total asset, and labor cost as the input, while loan and operating income as the output. The constant return to scale model was used in their study. The results of their study showed that the efficiency score of all Islamic banks from the second quarter of 2010 until the fourth quarter of 2012 fluctuated. None of the Islamic banks had a stable efficiency score during their observation. The highest efficiency score was $91.89 \%$ in the fourth quarter of 2011 , and the lowest score was $78.46 \%$ in the second quarter of 2011.

Several researchers have studied the Malmquist Productivity Index (MPI) to determine the productivity change in a particular period. In Europe, MPI was applied by Berger and Humpherey (1992) using Norwegian banks to evaluate the deregulation effect in the banking sector. Their finding empirically showed that productivity decreased before the deregulation had been implemented, and it increased after the deregulation was implemented. Using the same method, Sufian (2007) studied the difference of productivity index, technological change, efficiency change, as well as scale efficiency using intermediation variable approach. His research also tested whether domestic and foreign banks were formed by the same environment. The result of his research showed that the productivity of Islamic banks in Malaysia had Ushape behavior. Another finding showed that domestic banks had higher productivity than foreign banks did. Most of the middle-size Islamic banks in Malaysia had higher productivity because they utilized more advanced technology. The smaller Islamic banks in Malaysia had a lower productivity level because they were left behind in terms of technology.

Raphael (2013) investigated the productivity change of 21 commercial banks in Tanzania from 
Jurnal Bisnis dan Manajemen, Volume 20, No. 2, September 2019, p. 145-174

2005 to 2011 using the Malmquist Productivity Index (MPI) approach. In the intermediation variable approach, Raphael (2013) used panel data of 146 observations to be further analyzed. The result of his research showed that most of the commercial banks experienced an increase in their efficiency change by $67 \%$, technological change by $83 \%$, pure efficiency change by $67 \%$, and scale efficiency change by $50 \%$. Abbas et. al (2015) implemented the DEA method and Malmquist Index to evaluate the performance of Islamic and conventional banks in Pakistan for the period of 2005 to 2009. The result of their research showed that the productivity growth index of Islamic banks was higher than conventional banks in the years 2007 and 2008.

Nonetheless, in 2009, conventional banks had a higher productivity change. Malmquist TFP index showed that technological change index was the primary factor of productivity deterioration of Islamic banks. Thus, they were deemed as inefficient-scale banks.

Depren and Depren (2016) evaluated the efficiency of twenty deposit banks in Turkey from March 2014 to March 2015 using DEA and MPI. The input and output variables were prepared using intermediation and production approach. The result of their research showed that there were 11 and 14 efficient banks in 2014 and 2015. In the intermediation approach, sectoral efficiency decreased from 1.026 in 2014 to 1.018 in 2015. Besides, there were 12 efficient banks in terms of the total productivity index of Malmquist. In the production approach, the efficiency score of the banking sector in Turkey increased from 0.916 in 2014 to 0.926 in 2015 . However, the banking sector in Turkey was not efficient in terms of MPI.

This research differs from the previous research because the scope of this research is wider by preparing variables from three different approaches, namely, intermediation, operation, and the asset approach. Also, this research extends the observation period (from 2011 to 2016), allowing the comparison of the efficiency score of all DMUs (or IRDBs) in each approach and period. Also, panel data allows us to utilize Malmquist Productivity Index in determining the productivity change of each IRDB. So, it will help us draw a more complexed conclusion for resulting in better suggestions to support the improvement of IRDBs.

\section{METHODS}

The performance measurement using DEA starts by determining the input and output variable. According to Sealey and Lindley (1997), the primary approach to measure input and output variables of a bank is production and intermediation approach. Berger and Humphrey (1997) stated that the production approach is better for evaluating the efficiency of the branch of a financial institution. Initially, Berger and Humphrey (1997) commented the difficulty in selecting variables in bank performance using DEA because there is no a perfect approach in the explicit 
Jurnal Bisnis dan Manajemen, Volume 20, No. 2, September 2019, p. 145-174

definition and input as well as output measurement of a bank. Afsharian et al. (2016) proposed a solution to handle the issue of each input/output factor determination regarding the factor selection by developing Generalized DEA (GDEA).

Nonetheless, that approach requires us to explicitly determine the linear cost assumption and utility function. Besides, GDEA implementation is more recommended for benchmarking practice, and it is less practical to be implemented in this study. Therefore, this study uses three different approaches (as explained earlier) in the variable selection based on the list of input and output from the previous studies and the data availability. It is shown in Table 2 as follows.

Table 2. Variable of Input and Output

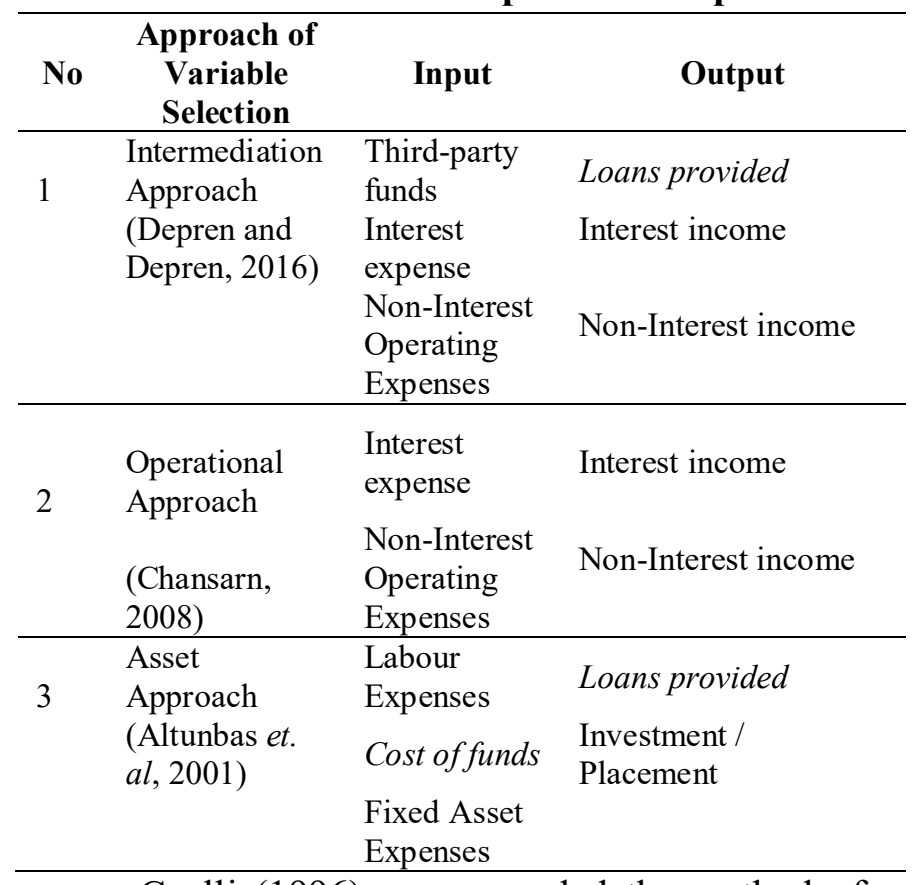

multi-stage DEA, instead of the other alternatives

(one-stage and two-stage DEA). Multi-stage DEA allows us to identify the efficient projection points, which have close input and output combinations, with the inefficient points and invariant for the measurement unit. The input-orientated measure shows the number of input, which can be proportionally reduced without having to change the number of the resulted output. Thus, input-orientated measure determines the input deduction needed to reach efficient performance in a similar output. Fethi and Pasiouras (2010) stated that banking industry using input-oriented measure assumes that bank managers have more control over the input variables (such as cost and employees) than the output variables (such as loan and income). Casy and Molyneux (2003) and most of the researchers tended to select input-orientated measures because the total input becomes the primary consideration in determining the variable, even though this reason may not be applied for all industries.

A high competition, financial barriers, and other factors may result in DMU to operate less optimally. Banker, Charnes, and Cooper (1998) suggested the extension of Variable Return to Scale, and this research uses this assumption because the condition of the banking industry in Indonesia is appropriate with that assumption. Besides, the VRS model is appropriate for a large sample size (Avkiran, 1999). Ferdian and Purwantoro (2006) generally measured the efficiency with the following formula:

\section{Efficiency $=\underline{\text { Input }}$}


Jurnal Bisnis dan Manajemen, Volume 20, No. 2, September 2019, p. 145-174

\section{Output}

Nonetheless, that equation is no longer appropriate because of the large number of input and output. Thus, the efficiency score in this study uses the following equation:

\section{Efficiency $=\underline{\text { Weighted sum of inputs }}$ Weighted sum of outputs}

$\mathrm{e}_{i}=\frac{\sum_{r=1}^{n} u_{x} y_{v j}}{\sum_{i=1}^{m} v_{j} x_{i j}}$

with,

ej $=$ bank efficiency $\mathrm{j}$

$\mathrm{n}=$ total bank output $\mathrm{j}$

$\mathrm{m}=$ total bank input $\mathrm{j}$

$\mathrm{Ur}=$ value of output $\mathrm{r}$

$\mathrm{yrj}=$ number of output $\mathrm{r}$ from bank $\mathrm{j}$

$\mathrm{vi}=$ input value $\mathrm{i}$

$x r j=$ number of inputs $r$ from banks $j$

Meanwhile, the manual equation to calculate efficiency using Variable Return to Scale with inputorientated measure according to Banker, Charnes, and Cooper (1998) is as follows:

Efficiency Change $=\frac{d_{0}{ }^{t}\left(x_{t+1}, y_{t+1}\right)}{d_{0}{ }^{t}\left(x_{t}, y_{t}\right)}$
Technical Change $=\left[\frac{d_{0}{ }^{t}\left(x_{t+1}, y_{t+1}\right)}{d_{0}{ }^{t+1}\left(x_{t+1}, y_{t+1}\right)} \times \frac{d_{0}^{t}\left(x_{t}, y_{t}\right)}{d_{0}^{t+1}\left(x_{t}, y_{t}\right)}\right]^{1 / 2}$

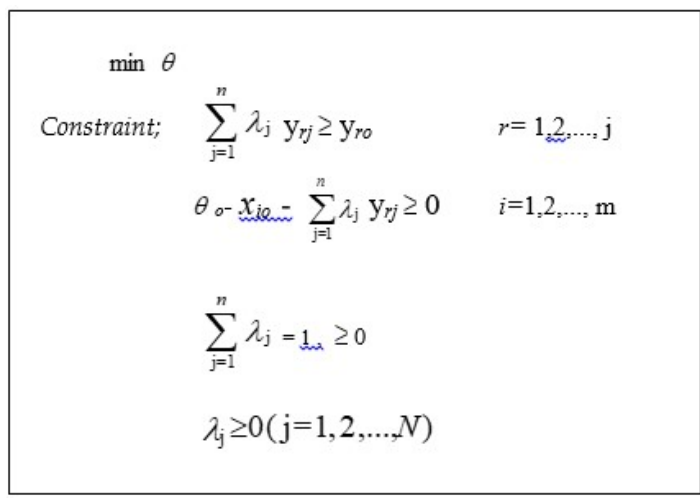

with,

$=$ technical efficiency bank

$x i j=$ number of inputs $-i$ bank $-j$

$\mathrm{yrj}=$ number of outputs $-\mathrm{r}$ of bank $-\mathrm{j}$

$1\{<1$ inefficient; $=1$ efficient $\}$

\section{Malmquist-DEA Analysis}

The DEA approach with index number can be used as an alternative in measuring the change in productivity. Several researchers used the Fisher index, Tomqvist index, and Malmquist index. This study uses Malmquist, as has been used by several researchers studying bank efficiency because there is no need to do profit maximization or cost minimization. Besides, since the data used is panel data, this approach facilitates the decomposition of productivity change to be technical efficiency change or to chase the lag and technical change. This study adopts the model as initiated by Fare et al. (1994) as follows:

$$
M_{0}\left(y_{t+1}, x_{t+1}, y_{t}, x_{t}\right)=\left[\frac{d_{0}{ }^{t}\left(x_{t+1}, y_{t+1}\right)}{d_{0}{ }^{t}\left(x_{t}, y_{t}\right)} \times \frac{d_{0}^{t+1}\left(x_{t+1}, y_{t+1}\right)}{d_{0}{ }^{t+1}\left(x_{t}, y_{t}\right)}\right]^{1 / 2}
$$

The above equation represents the productivity of production point $(\mathrm{xt}+1$, yt +1$)$, relative to the production point $(\mathrm{xt}, \mathrm{yt})$. The value 
Jurnal Bisnis dan Manajemen, Volume 20, No. 2, September 2019, p. 145-174

larger than one shows the growth of total productivity of period to the next period $(t+1)$, but the index is a mean geometric of two outputs based on the Malmquist index. The Malmquist productivity index based on the above output can be formulated as follows (Fare et al., 1992):

If there is no significant change between the time interval, which can be illustrated by $x t=x t+1$, and $\mathrm{yt}=\mathrm{yt}+1$, then MPI equals to 1 . Therefore, productivity change is stated in the following indexes, namely MPI $=1$ means steady, MPI $<1$ means declining, and MPI $>1$ means increasing.

According to Coelli (1996), VRS and CRS are assumed not to affect DEA Malmquist because both of them are used to measure the distance variation (or technical efficiency), which can be used to develop Malmquist index. Four distances were calculated for each company every year. It is relative to CRS DEA frontier of the previous period; CRS DEA frontier of the current period; CRS DEA frontier of the next period; and VRS frontier of the current period. Malmquist index has three advantages compared to other indexes, namely (Grifell-Tatje and Lovell, 1996): (1) It does not need the assumption of maximizing profit or minimizing cost; (2) It does not require input and output price; (3) Productivity change can be outlined to be technical efficiency change and pure technical change.

All Malmquist indexes are provided relative to the previous year. Thus, the input starts in the second year. Five indexes are provided for each company every year (Fare et. al, 1994), namely (1) technical efficiency change (Effch); technological change (Techch); (3) pure efficiency change (Pech); (4) scale efficiency change (Sech); and (5) total factor productivity change (Tfpch).

Malmquist index is the measurement of total factor productivity change (Tfpch) in a particular period. It portrays the performance of the entire company in a specific period. If the value is larger than one, the company has succeeded in increasing productivity. If the value is less than one, the company has declining productivity. Moreover, so for $M$. If $M$ equals to one, the company has succeeded in maintaining the previous productivity level. This principle also applies to Effch and Techch, representing efficiency and technology improvement. Besides, it is crucial to clarify whether the change in technical efficiency is caused by pure technical efficiency or technological improvement. If Techch is larger than Pech, it can be said that the productivity change is not caused by better efficiency in the company, but by the technological improvement, conversely. Besides, if Pech is larger than Sech, then the change in efficiency is caused by the change in efficiency, not by the scale, conversely. Charnes et al. (1993) and Worthington (1999) provided a detailed explanation regarding this interpretation. 
Jurnal Bisnis dan Manajemen, Volume 20, No. 2, September 2019, p. 145-174

\section{RESULTS AND DISCUSSION}

\section{Descriptive Statistics}

Table 4 describes the performance of input and output of all IRDBs throughout Indonesia in 20112016. Third-party funds of all IRDBs increased significantly during that period. The lowest value was in 2012 of 703,051 (in million rupiahs), and the highest value was in 2016 of 72,827,957 (in million rupiahs). Thus, the third-party fund increased by $60.19 \%$ in the last six years. Interest expense is the second input through the intermediation approach and the first input through the operation approach.

The average value of interest expense consistently increased from 2011 to 2015 and declined in 2016 by $5.2 \%$ as a result of the decrease in the reference interest rate. The maximum increase of non-interest expense was significant from 2011 to 2016 by $162.4 \%$. The largest move was shown in 2015 by 3,730,665 (in million rupiahs) and 2016 by $5,316,500$ (in million rupiahs). In other words, it increased by $42.5 \%$ from the previous period. It means that there was an increase in operational expenses such as general expense, labor expense, IT expense, and non-interest expense. The loan granted to the debtor in 2016 reached $81.1 \%$. The interest income consistently grew from 2011 to 2015, meaning that the performance of IRDBs in providing loan got better. The labor expense also increased, reaching a maximum of $13.9 \%$ in 2016. The minimum value of the cost of the fund increased by $12.5 \%$ from 2011 to 2016 . Besides, the cost of APPROACH AND MALMQUIST PRODUCTIVITY INDEX

(Efa Yonnedi, Abdul Rahman Panjaitan)

physical capital substantially declined by $301 \%$ in terms of standard deviation and the securities increased by $142.1 \%$ from the previous six years. These results are shown in Table 3. 
Jurnal Bisnis dan Manajemen, Volume 20, No. 2, September 2019, p. 145-174

The efficiency of IRDBs throughout Indonesia: Intermediation Approach

The analysis result using multi-stage DEA using the intermediation variable in Table 4 shows that only $28.0 \%$ or 7 BPDs were consistently efficient from 2011 to 2016 . The rest of $72.0 \%$ or 18 BPDs were not consistently efficient, having the lowest average score of 0.760 . The average efficiency score in six years was 0.936 , showing that $40.0 \%$ or 10 BPDs had the efficiency score below the average. The best achievement was in 2014 , where $72.8 \%$ or 18 BPDs ran intermediation function efficiently.

Table 4. Overall IRDBs Efficiency with Variable Intermediation Approach

\begin{tabular}{|c|c|c|c|c|c|c|c|c|}
\hline \multirow{2}{*}{ No } & \multirow{2}{*}{ IRDB } & \multicolumn{6}{|c|}{ Year } & \multirow{2}{*}{ Average } \\
\hline & & 2011 & 2012 & 2013 & 2014 & 2015 & 2016 & \\
\hline 1 & A01 & 1,000 & 1,000 & 1,000 & 1,000 & 1,000 & 1,000 & 1,000 \\
\hline 2 & A02 & 1,000 & 1,000 & 1,000 & 1,000 & 1,000 & 1,000 & 1,000 \\
\hline 3 & A06 & 1,000 & 1,000 & 1,000 & 1,000 & 1,000 & 1,000 & 1,000 \\
\hline 4 & A08 & 1,000 & 1,000 & 1,000 & 1,000 & 1,000 & 1,000 & 1,000 \\
\hline 5 & A23 & 1,000 & 1,000 & 1,000 & 1,000 & 1,000 & 1,000 & 1,000 \\
\hline 6 & A20 & 1,000 & 1,000 & 1,000 & 1,000 & 1,000 & 1,000 & 1,000 \\
\hline 7 & A18 & 1,000 & 1,000 & 1,000 & 1,000 & 1,000 & 1,000 & 1,000 \\
\hline 8 & A04 & 0,984 & 1,000 & 1,000 & 0,961 & 1,000 & 1,000 & 0,991 \\
\hline 9 & A24 & 1,000 & 1,000 & 0,925 & 1,000 & 1,000 & 0,976 & 0,984 \\
\hline 10 & A16 & 0,901 & 0,994 & 1,000 & 1,000 & 1,000 & 1,000 & 0,983 \\
\hline 11 & A19 & 1,000 & 0,893 & 1,000 & 1,000 & 1,000 & 1,000 & 0,982 \\
\hline 12 & A17 & 1,000 & 1,000 & 1,000 & 0,903 & 1,000 & 0,965 & 0,978 \\
\hline 13 & A11 & 1,000 & 1,000 & 0,938 & 1,000 & 0,900 & 1,000 & 0,973 \\
\hline 14 & A03 & 0,713 & 1,000 & 1,000 & 1,000 & 1,000 & 1,000 & 0,952 \\
\hline 15 & A14 & 1,000 & 0,906 & 0,885 & 0,945 & 0,954 & 0,982 & 0,945 \\
\hline 16 & A09 & 1,000 & 1,000 & 0,887 & 0,977 & 0,842 & 0,885 & 0,932 \\
\hline 17 & A22 & 1,000 & 0,779 & 1,000 & 1,000 & 0,877 & 0,875 & 0,922 \\
\hline 18 & A15 & 0,822 & 0,801 & 0,772 & 1,000 & 1,000 & 1,000 & 0,899 \\
\hline 19 & A 25 & 0,534 & 0,857 & 1,000 & 1,000 & 1,000 & 1,000 & 0,899 \\
\hline 20 & A05 & 0,960 & 0,796 & 0,697 & 0,879 & 1,000 & 1,000 & 0,889 \\
\hline 21 & A07 & 0,652 & 0,791 & 0,795 & 1,000 & 1,000 & 1,000 & 0,873 \\
\hline 22 & A13 & 1,000 & 0,490 & 0,655 & 0,874 & 1,000 & 1,000 & 0,837 \\
\hline 23 & A21 & 0,554 & 0,633 & 1,000 & 0,904 & 0,964 & 0,905 & 0,827 \\
\hline 24 & A10 & 0,596 & 0,710 & 0,680 & 0,930 & 0,882 & 0,882 & 0,780 \\
\hline \multirow[t]{6}{*}{25} & A 12 & 0,455 & 0,884 & 0,724 & 0,794 & 0,902 & 0,802 & 0,760 \\
\hline & Lowest & 0,455 & 0,490 & 0,655 & 0,794 & 0,842 & 0,802 & 0,760 \\
\hline & Highest & 1,000 & 1,000 & 1,000 & 1,000 & 1,000 & 1,000 & 1,000 \\
\hline & Average & 0,887 & 0,901 & 0,918 & 0,967 & 0,973 & 0,971 & 0,936 \\
\hline & Efficient IRDBs & 15 & 13 & 15 & 16 & 18 & 17 & 7 \\
\hline & Inefficient IRDBs & 10 & 12 & 10 & 9 & 7 & 8 & 18 \\
\hline
\end{tabular}

Source: processed data

EFFICIENCY AND PRODUCTIVITY ANALYSIS OF INDONESIAN REGIONAL DEVELOPMENT BANKS: MULTI-STAGE DEA APPROACH AND MALMQUIST PRODUCTIVITY INDEX

(Efa Yonnedi, Abdul Rahman Panjaitan) 
Jurnal Bisnis dan Manajemen, Volume 20, No. 2, September 2019, p. 145-174

Based on BUKU category or core capital size, IRDBs in BUKU 3 category had an average of 0.984. Meanwhile, in BUKU category 2 had an average of 0.912 , and in BUKU category 1 had an average of 0.955 . Although these numbers do not differ significantly, it can be said that the IRDBs with the most considerable core capital had the highest efficiency.

Table 5. IRDBs Efficiency Based on BUKU Category with Variable Intermediation Approach

\begin{tabular}{|c|c|c|c|c|c|c|c|c|}
\hline \multirow{2}{*}{ No } & \multirow{2}{*}{ IRDBs } & \multicolumn{6}{|c|}{ Year } & \multirow{2}{*}{ Category } \\
\hline & & 2011 & & 2013 & 2014 & 2015 & 2016 & \\
\hline 1 & A01 & 1,000 & 1,000 & 1,000 & 1,000 & 1,000 & 1,000 & \\
\hline 2 & $\mathrm{~A} 02$ & 1,000 & 1,000 & 1,000 & 1,000 & 1,000 & 1,000 & BUKU 3 \\
\hline \multirow[t]{2}{*}{3} & $\mathrm{~A} 03$ & 0,713 & 1,000 & 1,000 & 1,000 & 1,000 & 1,000 & \\
\hline & Average & 0,904 & 1,000 & 1,000 & 1,000 & 1,000 & 1,000 & 0,984 \\
\hline 4 & A04 & 0,984 & 1,000 & 1,000 & 0,961 & 1,000 & 1,000 & \\
\hline 5 & A05 & 0,960 & 0,796 & 0,697 & 0,879 & 1,000 & 1,000 & \\
\hline 6 & A06 & 1,000 & 1,000 & 1,000 & 1,000 & 1,000 & 1,000 & \\
\hline 7 & A07 & 0,652 & 0,791 & 0,795 & 1,000 & 1,000 & 1,000 & \\
\hline 8 & A08 & 1,000 & 1,000 & 1,000 & 1,000 & 1,000 & 1,000 & \\
\hline 9 & A09 & 1,000 & 1,000 & 0,887 & 0,977 & 0,842 & 0,885 & \\
\hline 10 & A10 & 0,596 & 0,710 & 0,680 & 0,930 & 0,882 & 0,882 & BUKU 2 \\
\hline 11 & A11 & 1,000 & 1,000 & 0,938 & 1,000 & 0,900 & 1,000 & \\
\hline 12 & A12 & 0,455 & 0,884 & 0,724 & 0,794 & 0,902 & 0,802 & \\
\hline 13 & A13 & 1,000 & 0,490 & 0,655 & 0,874 & 1,000 & 1,000 & \\
\hline 14 & A14 & 1,000 & 0,906 & 0,885 & 0,945 & 0,954 & 0,982 & \\
\hline 15 & A15 & 0,822 & 0,801 & 0,772 & 1,000 & 1,000 & 1,000 & \\
\hline \multirow[t]{2}{*}{16} & A16 & 0,901 & 0,994 & 1,000 & 1,000 & 1,000 & 1,000 & \\
\hline & Average & 0,875 & 0,875 & 0,849 & 0,951 & 0,960 & 0,965 & 0,912 \\
\hline 17 & A17 & 1,000 & 1,000 & 1,000 & 0,903 & 1,000 & 0,965 & \\
\hline 18 & A18 & 1,000 & 1,000 & 1,000 & 1,000 & 1,000 & 1,000 & \\
\hline 19 & A19 & 1,000 & 0,893 & 1,000 & 1,000 & 1,000 & 1,000 & \\
\hline 20 & A20 & 1,000 & 1,000 & 1,000 & 1,000 & 1,000 & 1,000 & \\
\hline 21 & A21 & 0,554 & 0,633 & 1,000 & 0,904 & 0,964 & 0,905 & BUKU 1 \\
\hline 22 & A22 & 1,000 & 0,779 & 1,000 & 1,000 & 0,877 & 0,875 & \\
\hline 23 & A23 & 1,000 & 1,000 & 1,000 & 1,000 & 1,000 & 1,000 & \\
\hline 24 & A24 & 1,000 & 1,000 & 0,925 & 1,000 & 1,000 & 0,976 & \\
\hline \multirow[t]{2}{*}{25} & A25 & 0,534 & 0,857 & 1,000 & 1,000 & 1,000 & 1,000 & \\
\hline & Average & 0,899 & 0,907 & 0,992 & 0,979 & 0,982 & 0,969 & 0,955 \\
\hline
\end{tabular}


Jurnal Bisnis dan Manajemen, Volume 20, No. 2, September 2019, p. 145-174

Efficiency IRDBs throughout Indonesia:
Operational Approach Based on table 6 , it is known that the mean or average efficiency score using the operation variable approach of IRDBs throughout Indonesia is 0.824 for the year 2011 to 2016. The number of efficient IRDBs was $24.0 \%$ or 6 IRDBs, while the rest of
$76.0 \%$ was considered insufficient. We found that 13 IRDBs had a score lower than the average. In other words, $52.0 \%$ of the inefficient IRDBs operated below the performance of the IRDBs on average. The lowest efficiency score in that six-year-period was 0.515 .

Table 6. Overall IRDBs Efficiency with Operation Variable Approach

\begin{tabular}{|c|c|c|c|c|c|c|c|c|}
\hline \multirow{2}{*}{ No } & \multirow{2}{*}{ IRDBs } & \multicolumn{6}{|c|}{ Year } & \multirow{2}{*}{ Average } \\
\hline & & 2011 & 2012 & 2013 & 2014 & 2015 & 2016 & \\
\hline 1 & A01 & 1,000 & 1,000 & 1,000 & 1,000 & 1,000 & 1,000 & 1,000 \\
\hline 2 & A02 & 1,000 & 1,000 & 1,000 & 1,000 & 1,000 & 1,000 & 1,000 \\
\hline 3 & A06 & 1,000 & 1,000 & 1,000 & 1,000 & 1,000 & 1,000 & 1,000 \\
\hline 4 & A08 & 1,000 & 1,000 & 1,000 & 1,000 & 1,000 & 1,000 & 1,000 \\
\hline 5 & A23 & 1,000 & 1,000 & 1,000 & 1,000 & 1,000 & 1,000 & 1,000 \\
\hline 6 & A20 & 1,000 & 1,000 & 1,000 & 1,000 & 1,000 & 1,000 & 1,000 \\
\hline 7 & A16 & 0,892 & 0,918 & 1,000 & 1,000 & 1,000 & 1,000 & 0,968 \\
\hline 8 & A03 & 0,697 & 1,000 & 1,000 & 1,000 & 1,000 & 1,000 & 0,950 \\
\hline 9 & A19 & 0,879 & 0,803 & 1,000 & 1,000 & 1,000 & 1,000 & 0,947 \\
\hline 10 & A17 & 1,000 & 1,000 & 0,928 & 0,724 & 0,925 & 0,930 & 0,918 \\
\hline 11 & A09 & 1,000 & 1,000 & 0,887 & 0,977 & 0,693 & 0,708 & 0,878 \\
\hline 12 & A24 & 1,000 & 1,000 & 0,804 & 0,801 & 0,735 & 0,701 & 0,840 \\
\hline 13 & A11 & 1,000 & 0,873 & 0,655 & 0,685 & 0,809 & 0,920 & 0,824 \\
\hline 14 & A04 & 0,781 & 0,884 & 0,681 & 0,775 & 0,776 & 1,000 & 0,816 \\
\hline 15 & A14 & 1,000 & 0,786 & 0,708 & 0,781 & 0,747 & 0,773 & 0,799 \\
\hline 16 & A22 & 0,647 & 0,572 & 1,000 & 0,870 & 0,781 & 0,875 & 0,791 \\
\hline 17 & A18 & 1,000 & 0,922 & 0,812 & 0,660 & 0,655 & 0,685 & 0,789 \\
\hline 18 & A25 & 0,495 & 0,531 & 1,000 & 0,777 & 0,759 & 0,797 & 0,727 \\
\hline 19 & A21 & 0,489 & 0,432 & 1,000 & 0,650 & 0,715 & 0,896 & 0,697 \\
\hline 20 & A15 & 0,803 & 0,481 & 0,471 & 0,590 & 0,904 & 0,806 & 0,676 \\
\hline 21 & A07 & 0,603 & 0,617 & 0,570 & 0,645 & 0,618 & 0,849 & 0,650 \\
\hline 22 & $\mathrm{~A} 05$ & 0,960 & 0,792 & 0,407 & 0,550 & 0,505 & 0,632 & 0,641 \\
\hline 23 & A12 & 0,424 & 0,605 & 0,548 & 0,568 & 0,817 & 0,714 & 0,613 \\
\hline 24 & A10 & 0,547 & 0,543 & 0,501 & 0,524 & 0,557 & 0,665 & 0,556 \\
\hline \multirow[t]{6}{*}{25} & A13 & 0,504 & 0,427 & 0,465 & 0,550 & 0,567 & 0,578 & 0,515 \\
\hline & Lowest & 0,424 & 0,427 & 0,407 & 0,524 & 0,505 & 0,578 & 0,515 \\
\hline & Highest & 1,000 & 1,000 & 1,000 & 1,000 & 1,000 & 1,000 & 1,000 \\
\hline & Average & 0,829 & 0,807 & 0,817 & 0,805 & 0,823 & 0,861 & 0,824 \\
\hline & Efficient IRDBs & 12 & 10 & 12 & 9 & 9 & 10 & 6 \\
\hline & Inefficient IRDBs & 13 & 15 & 13 & 16 & 16 & 15 & 19 \\
\hline
\end{tabular}

Source: processed data 
Jurnal Bisnis dan Manajemen, Volume 20, No. 2, September 2019, p. 145-174

Also, as shown in table 7, in the operational variable approach, the IRDBs in BUKU 3 category had an efficiency score of 0.983 . It indicates that there is a significant difference from IRDBs in BUKU category 2 and 1, which had an average efficiency of 0.764 and 0.856 . Therefore, the operation variable approach also supports the idea that IRDBs with a large core capital has the highest average efficiency score.

Table 7. IRDBs Efficiency Based on BUKU Category with Operational Variable Approach

\begin{tabular}{|c|c|c|c|c|c|c|c|c|}
\hline \multirow{2}{*}{ No } & \multirow{2}{*}{ IRDBs } & \multicolumn{6}{|c|}{ Year } & \multirow{2}{*}{ Category } \\
\hline & & 2011 & 2012 & 2013 & 2014 & 2015 & 2016 & \\
\hline 1 & A01 & 1,000 & 1,000 & 1,000 & 1,000 & 1,000 & 1,000 & \\
\hline 2 & A02 & 1,000 & 1,000 & 1,000 & 1,000 & 1,000 & 1,000 & BUKU 3 \\
\hline \multirow[t]{2}{*}{3} & A03 & 0,697 & 1,000 & 1,000 & 1,000 & 1,000 & 1,000 & \\
\hline & Average & 0,899 & 1,000 & 1,000 & 1,000 & 1,000 & 1,000 & 0,983 \\
\hline 4 & A04 & 0,781 & 0,884 & 0,681 & 0,775 & 0,776 & 1,000 & \\
\hline 5 & A05 & 0,960 & 0,792 & 0,407 & 0,550 & 0,505 & 0,632 & \\
\hline 6 & A06 & 1,000 & 1,000 & 1,000 & 1,000 & 1,000 & 1,000 & \\
\hline 7 & A07 & 0,603 & 0,617 & 0,570 & 0,645 & 0,618 & 0,849 & \\
\hline 8 & A08 & 1,000 & 1,000 & 1,000 & 1,000 & 1,000 & 1,000 & \\
\hline 9 & A09 & 1,000 & 1,000 & 0,887 & 0,977 & 0,693 & 0,708 & \\
\hline 10 & A10 & 0,547 & 0,543 & 0,501 & 0,524 & 0,557 & 0,665 & BUKU 2 \\
\hline 11 & A11 & 1,000 & 0,873 & 0,655 & 0,685 & 0,809 & 0,920 & \\
\hline 12 & A12 & 0,424 & 0,605 & 0,548 & 0,568 & 0,817 & 0,714 & \\
\hline 13 & A13 & 0,504 & 0,427 & 0,465 & 0,550 & 0,567 & 0,578 & \\
\hline 14 & A14 & 1,000 & 0,786 & 0,708 & 0,781 & 0,747 & 0,773 & \\
\hline 15 & A 15 & 0,803 & 0,481 & 0,471 & 0,590 & 0,904 & 0,806 & \\
\hline \multirow[t]{2}{*}{16} & A16 & 0,892 & 0,918 & 1,000 & 1,000 & 1,000 & 1,000 & \\
\hline & Average & 0,809 & 0,764 & 0,684 & 0,742 & 0,769 & 0,819 & 0,764 \\
\hline 17 & A17 & 1,000 & 1,000 & 0,928 & 0,724 & 0,925 & 0,930 & \\
\hline 18 & A18 & 1,000 & 0,922 & 0,812 & 0,660 & 0,655 & 0,685 & \\
\hline 19 & A19 & 0,879 & 0,803 & 1,000 & 1,000 & 1,000 & 1,000 & \\
\hline 20 & A20 & 1,000 & 1,000 & 1,000 & 1,000 & 1,000 & 1,000 & \\
\hline 21 & A 21 & 0,489 & 0,432 & 1,000 & 0,650 & 0,715 & 0,896 & BUKU 1 \\
\hline 22 & $\mathrm{~A} 22$ & 0,647 & 0,572 & 1,000 & 0,870 & 0,781 & 0,875 & \\
\hline 23 & A23 & 1,000 & 1,000 & 1,000 & 1,000 & 1,000 & 1,000 & \\
\hline 24 & A24 & 1,000 & 1,000 & 0,804 & 0,801 & 0,735 & 0,701 & \\
\hline \multirow[t]{2}{*}{25} & A 25 & 0,495 & 0,531 & 1,000 & 0,777 & 0,759 & 0,797 & \\
\hline & Average & 0,834 & 0,807 & 0,949 & 0,831 & 0,841 & 0,876 & 0,856 \\
\hline
\end{tabular}


Jurnal Bisnis dan Manajemen, Volume 20, No. 2, September 2019, p. 145-174

Efficiency IRDBs throughout Indonesia: Asset Approach

From 2011 until 2016, using asset variable approach, we found that only two IRDBs were efficient, as shown in Table 8. The rest of the 23 IRDBs were not efficient. The average efficiency score of IRDBs
0.836. The lowest score of the inefficient IRDBs was 0.515 . Besides, of the $80.0 \%$ inefficient IRDBs, we found that $52.2 \%$ of them operated under the average performance.

Table 8. Overall IRDBs Efficiency with Asset Variable Approach

\begin{tabular}{|c|c|c|c|c|c|c|c|c|}
\hline \multirow{2}{*}{ No } & \multirow{2}{*}{ IRDBs } & \multicolumn{6}{|c|}{ Year } & \multirow{2}{*}{ Average } \\
\hline & & 2011 & 2012 & 2013 & 2014 & 2015 & 2016 & \\
\hline 1 & A01 & 1,000 & 1,000 & 1,000 & 1,000 & 1,000 & 1,000 & 1,000 \\
\hline 2 & A02 & 1,000 & 1,000 & 1,000 & 1,000 & 1,000 & 1,000 & 1,000 \\
\hline 3 & A05 & 1,000 & 1,000 & 1,000 & 1,000 & 1,000 & 0,968 & 0,995 \\
\hline 4 & A08 & 1,000 & 1,000 & 1,000 & 1,000 & 0,909 & 1,000 & 0,985 \\
\hline 5 & A09 & 1,000 & 0,861 & 1,000 & 1,000 & 1,000 & 0,984 & 0,974 \\
\hline 6 & A19 & 1,000 & 0,781 & 1,000 & 1,000 & 1,000 & 1,000 & 0,964 \\
\hline 7 & A13 & 1,000 & 0,981 & 1,000 & 1,000 & 0,842 & 0,909 & 0,955 \\
\hline 8 & A16 & 0,904 & 0,830 & 1,000 & 0,948 & 1,000 & 1,000 & 0,947 \\
\hline 9 & A20 & 0,920 & 1,000 & 1,000 & 1,000 & 0,805 & 0,932 & 0,943 \\
\hline 10 & A03 & 0,799 & 0,801 & 0,962 & 1,000 & 1,000 & 1,000 & 0,927 \\
\hline 11 & A04 & 0,977 & 0,933 & 1,000 & 0,817 & 0,785 & 1,000 & 0,919 \\
\hline 12 & A17 & 1,000 & 0,929 & 0,789 & 0,711 & 0,941 & 1,000 & 0,895 \\
\hline 13 & A14 & 0,861 & 0,843 & 0,925 & 0,997 & 0,749 & 0,916 & 0,882 \\
\hline 14 & A07 & 0,708 & 0,728 & 0,961 & 0,845 & 0,888 & 0,857 & 0,831 \\
\hline 15 & A10 & 0,645 & 0,852 & 1,000 & 0,860 & 0,766 & 0,782 & 0,818 \\
\hline 16 & A22 & 0,790 & 0,650 & 0,880 & 0,736 & 1,000 & 0,710 & 0,794 \\
\hline 17 & A12 & 0,677 & 0,700 & 0,968 & 0,801 & 0,762 & 0,770 & 0,780 \\
\hline 18 & A23 & 0,707 & 0,716 & 0,734 & 0,805 & 0,805 & 0,811 & 0,763 \\
\hline 19 & A06 & 0,702 & 0,631 & 0,897 & 0,759 & 0,726 & 0,722 & 0,740 \\
\hline 20 & A25 & 0,583 & 0,575 & 0,796 & 0,859 & 0,734 & 0,820 & 0,728 \\
\hline 21 & A11 & 0,601 & 0,569 & 0,718 & 0,724 & 0,606 & 0,898 & 0,686 \\
\hline 22 & A 21 & 0,633 & 0,574 & 0,687 & 0,653 & 0,580 & 0,679 & 0,634 \\
\hline 23 & A15 & 0,665 & 0,625 & 0,639 & 0,532 & 0,711 & 0,543 & 0,619 \\
\hline 24 & A24 & 0,728 & 0,537 & 0,712 & 0,602 & 0,516 & 0,598 & 0,616 \\
\hline \multirow[t]{6}{*}{25} & A18 & 0,459 & 0,466 & 0,560 & 0,580 & 0,546 & 0,478 & 0,515 \\
\hline & Lowest & 0,459 & 0,466 & 0,560 & 0,532 & 0,516 & 0,478 & 0,515 \\
\hline & Highest & 1,000 & 1,000 & 1,000 & 1,000 & 1,000 & 1,000 & 1,000 \\
\hline & Average & 0,814 & 0,783 & 0,889 & 0,849 & 0,827 & 0,855 & 0,836 \\
\hline & Efficient IRDBs & 8 & 5 & 11 & 9 & 8 & 8 & 2 \\
\hline & Inefficient IRDBs & 17 & 20 & 14 & 16 & 17 & 17 & 23 \\
\hline
\end{tabular}

Source: processed data 
Jurnal Bisnis dan Manajemen, Volume 20, No. 2, September 2019, p. 145-174

Table 9 shows the average efficiency based on BUKU category of 25 IRDBs using asset variable approach. The IRDBs in BUKU 1 had an average efficiency of 0.761, while IRDBs in BUKU 2 and 3 had higher scores, namely 0.856 and 0.976 .
Therefore, this approach also supports the results of the two previous approaches where the IRDBs with the large core capital had the highest efficiency score averagely.

Table 9. IRDBs Efficiency Based on BUKU Category with Asset Variable Approach

\begin{tabular}{|c|c|c|c|c|c|c|c|c|}
\hline \multirow{2}{*}{ No } & \multirow{2}{*}{ IRDB } & \multicolumn{6}{|c|}{ Year } & \multirow{2}{*}{-Category } \\
\hline & & 2011 & 2012 & 2013 & 2014 & 2015 & 2016 & \\
\hline 1 & A01 & 1,000 & 1,000 & 1,000 & 1,000 & 1,000 & 1,000 & \\
\hline 2 & A02 & 1,000 & 1,000 & 1,000 & 1,000 & 1,000 & 1,000 & BUKU 3 \\
\hline \multirow[t]{2}{*}{3} & A03 & 0,799 & 0,801 & 0,962 & 1,000 & 1,000 & 1,000 & \\
\hline & Average & 0,933 & 0,934 & 0,987 & 1,000 & 1,000 & 1,000 & 0,976 \\
\hline 4 & A04 & 0,977 & 0,933 & 1,000 & 0,817 & 0,785 & 1,000 & \\
\hline 5 & A05 & 1,000 & 1,000 & 1,000 & 1,000 & 1,000 & 0,968 & \\
\hline 6 & A06 & 0,702 & 0,631 & 0,897 & 0,759 & 0,726 & 0,722 & \\
\hline 7 & A07 & 0,708 & 0,728 & 0,961 & 0,845 & 0,888 & 0,857 & \\
\hline 8 & A08 & 1,000 & 1,000 & 1,000 & 1,000 & 0,909 & 1,000 & \\
\hline 9 & A09 & 1,000 & 0,861 & 1,000 & 1,000 & 1,000 & 0,984 & \\
\hline 10 & A10 & 0,645 & 0,852 & 1,000 & 0,860 & 0,766 & 0,782 & BUKU 2 \\
\hline 11 & A11 & 0,601 & 0,569 & 0,718 & 0,724 & 0,606 & 0,898 & \\
\hline 12 & A 12 & 0,677 & 0,700 & 0,968 & 0,801 & 0,762 & 0,770 & \\
\hline 13 & A13 & 1,000 & 0,981 & 1,000 & 1,000 & 0,842 & 0,909 & \\
\hline 14 & A14 & 0,861 & 0,843 & 0,925 & 0,997 & 0,749 & 0,916 & \\
\hline 15 & A15 & 0,665 & 0,625 & 0,639 & 0,532 & 0,711 & 0,543 & \\
\hline \multirow[t]{2}{*}{16} & A16 & 0,904 & 0,830 & 1,000 & 0,948 & 1,000 & 1,000 & \\
\hline & Average & 0,826 & $\mathbf{0 , 8 1 2}$ & 0,931 & 0,868 & 0,826 & $\mathbf{0 , 8 7 3}$ & 0,856 \\
\hline 17 & A17 & 1,000 & 0,929 & 0,789 & 0,711 & 0,941 & 1,000 & \\
\hline 18 & A18 & 0,459 & 0,466 & 0,560 & 0,580 & 0,546 & 0,478 & \\
\hline 19 & A19 & 1,000 & 0,781 & 1,000 & 1,000 & 1,000 & 1,000 & \\
\hline 20 & A20 & 0,920 & 1,000 & 1,000 & 1,000 & 0,805 & 0,932 & \\
\hline 21 & A21 & 0,633 & 0,574 & 0,687 & 0,653 & 0,580 & 0,679 & BUKU 1 \\
\hline 22 & A22 & 0,790 & 0,650 & 0,880 & 0,736 & 1,000 & 0,710 & \\
\hline 23 & A23 & 0,707 & 0,716 & 0,734 & 0,805 & 0,805 & 0,811 & \\
\hline 24 & A24 & 0,728 & 0,537 & 0,712 & 0,602 & 0,516 & 0,598 & \\
\hline \multirow[t]{2}{*}{25} & A25 & 0,583 & 0,575 & 0,796 & 0,859 & 0,734 & 0,820 & \\
\hline & Average & 0,758 & 0,692 & 0,795 & 0,772 & 0,770 & 0,781 & 0,761 \\
\hline
\end{tabular}


Jurnal Bisnis dan Manajemen, Volume 20, No. 2, September 2019, p. 145-174

\section{Efficiency Changes of IRDBS}

MPI of all IRDBs in 2011-2016 using intermediation variable approach shows that there are increases in efficiency change by $80.0 \%$, technological change by $20.0 \%$, pure technical change by $80.0 \%$, and scale efficiency change by $80.0 \%$. The declining tendency of efficiency change significantly happened in 2013 until 2015, increasing from $11.3 \%$ to $0.6 \%$. Meanwhile, technological change declined by $7.4 \%$ on average. Other Malmquist indexes show increases in productivity change, namely, the technical efficiency changes by $4.7 \%$, pure efficiency changes by $2.1 \%$, and scale efficiency changes by $2.5 \%$.

Table 10. Annual Average of Malmquist index using Intermediation Variable Approach

\begin{tabular}{cccccc}
\hline Period & Effch & Techch & Pech & Sech & Tfpch \\
\hline $2011 / 2012$ & 1,089 & 0,836 & 1,018 & 1,070 & 0,911 \\
$2012 / 2013$ & 1,026 & 0,986 & 1,012 & 1,013 & 1,011 \\
$2013 / 2014$ & 1,113 & 0,817 & 1,077 & 1,034 & 0,909 \\
$2014 / 2015$ & 0,994 & 1,010 & 1,001 & 0,993 & 1,004 \\
$2015 / 2016$ & 1,012 & 0,982 & 0,998 & 1,014 & 0,994 \\
Mean & $\mathbf{1 , 0 4 7}$ & $\mathbf{0 , 9 2 6}$ & $\mathbf{1 , 0 2 1}$ & $\mathbf{1 , 0 2 5}$ & $\mathbf{0 , 9 6 6}$ \\
\hline
\end{tabular}

Notes: Technical efficiency change (effch), technological change (techch), pure efficiency change (pech), scale Efficiency change (sech), total factor productivity change (tfpch)

The increase of total factor productivity change only happened in 2012/2013, increasing by
$1.1 \%$ and $2014 / 2015$ by $0.4 \%$. While in other periods declined by $8.9 \%$ in $2011 / 2012,9.1 \%$ in $2013 / 2014$, and $0.6 \%$ in $2015 / 2016$. Besides, the total factor productivity change of IRDBs declined by $3.4 \%$ during the observation period.

The fluctuation of total factor productivity, as shown in Figure 2, can be solved by sustainably increasing the indexes of technical efficiency change and technological change. 
Jurnal Bisnis dan Manajemen, Volume 20, No. 2, September 2019, p. 145-174

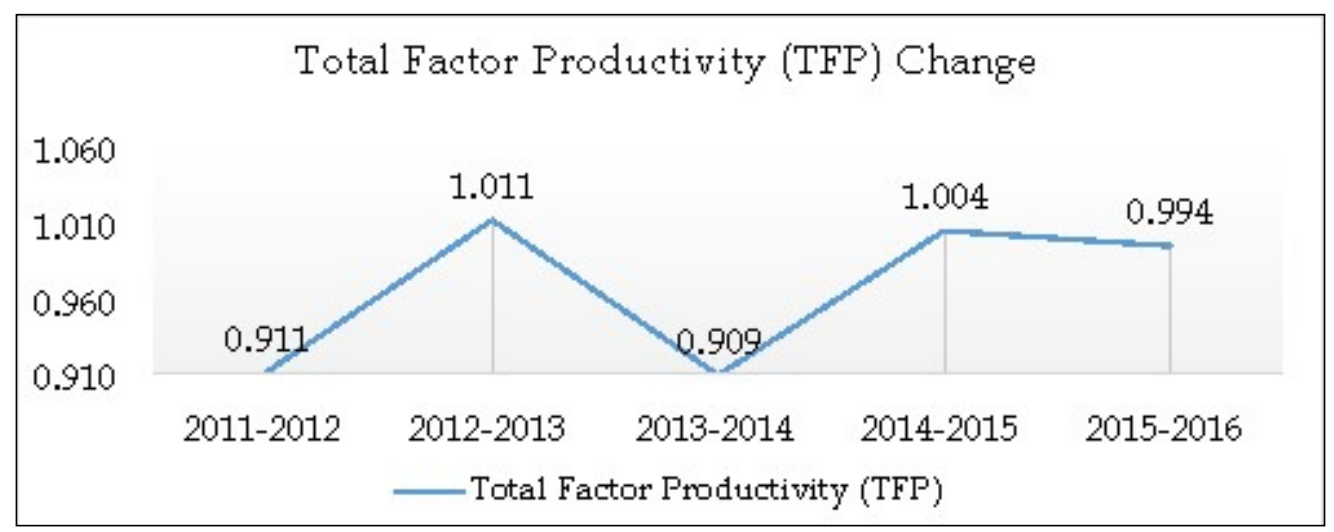

Figure 2. Total Factor Productivity Change with the Variable Intermediation Approach

Table 11 shows that most of the IRDBs increased their productivity in almost all Malmquist indices, except in technological change, declining by approximately $7.6 \%$. Productivity changes in other indexes are; $60.0 \%$ of IRDBs increased their efficiency change, $16.0 \%$ IRDBs had declining productivity, and $24.0 \%$ of them did not experience any productivity change. Around $44.0 \%$ of IRDBs had an increase in total factor productivity change, supported by the increase in index efficiency change and scale efficiency change.

Table 11. Average Malmquist Index IRDBs with Variable Intermediation Approach

\begin{tabular}{lllllll}
\hline No & IRDB & Effch & Techch & Pech & Sech & Tfpch \\
\hline 1 & A25 & 1,220 & 0,868 & 1,219 & 1,001 & 1,060 \\
2 & A05 & 1,079 & 0,970 & 1,006 & 1,073 & 1,047 \\
3 & A14 & 1,162 & 0,900 & 0,997 & 1,166 & 1,045 \\
4 & A12 & 1,116 & 0,935 & 1,095 & 1,019 & 1,043 \\
5 & A03 & 1,137 & 0,916 & 1,041 & 1,093 & 1,041 \\
6 & A06 & 1,000 & 1,038 & 1,000 & 1,000 & 1,038 \\
7 & A16 & 1,022 & 0,999 & 1,021 & 1,000 & 1,021 \\
8 & A07 & 1,093 & 0,933 & 1,070 & 1,022 & 1,020 \\
9 & A09 & 1,021 & 0,995 & 0,980 & 1,041 & 1,016 \\
10 & A10 & 1,085 & 0,936 & 1,040 & 1,044 & 1,016 \\
11 & A01 & 1,071 & 0,947 & 1,000 & 1,071 & 1,015 \\
12 & A21 & 1,104 & 0,902 & 1,109 & 0,995 & 0,996 \\
13 & A20 & 1,000 & 0,980 & 1,000 & 1,000 & 0,980 \\
14 & A02 & 1,043 & 0,931 & 1,000 & 1,043 & 0,972 \\
15 & A08 & 1,000 & 0,971 & 1,000 & 1,000 & 0,971 \\
16 & A17 & 0,991 & 0,977 & 0,992 & 0,999 & 0,969 \\
17 & A11 & 1,041 & 0,927 & 1,000 & 1,041 & 0,965 \\
18 & A15 & 1,044 & 0,923 & 1,032 & 1,012 & 0,964 \\
19 & A24 & 0,988 & 0,947 & 0,995 & 0,993 & 0,936 \\
20 & A18 & 1,000 & 0,933 & 1,000 & 1,000 & 0,933
\end{tabular}

EFFICIENCY AND PRODUCTIVITY ANALYSIS OF INDONESIAN REGIONAL DEVELOPMENT BANKS: MULTI-STAGE DEA APPROACH AND MALMQUIST PRODUCTIVITY INDEX

(Efa Yonnedi, Abdul Rahman Panjaitan) 
Jurnal Bisnis dan Manajemen, Volume 20, No. 2, September 2019, p. 145-174

\begin{tabular}{lllllll}
21 & A04 & 1,058 & 0,878 & 1,001 & 1,057 & 0,929 \\
22 & A13 & 1,000 & 0,862 & 1,000 & 1,000 & 0,862 \\
23 & A19 & 1,000 & 0,862 & 1,000 & 1,000 & 0,862 \\
24 & A22 & 0,940 & 0,827 & 0,954 & 0,985 & 0,777 \\
25 & A23 & 0,973 & 0,754 & 1,000 & 0,973 & 0,734 \\
& Average & $\mathbf{1 , 0 4 8}$ & $\mathbf{0 , 9 2 4}$ & $\mathbf{1 , 0 2 2}$ & $\mathbf{1 , 0 2 5}$ & $\mathbf{0 , 9 6 8}$ \\
\hline
\end{tabular}

Notes: Technical efficiency change (effch), technological change (techch), pure efficiency change (pech), scale Efficiency change (sech), total factor productivity change (tfpch)

Table 12 shows the value of Malmquist indices using the operation variable approach, which is slightly lower than the intermediation variable approach. During the observation period from 2011 to 2016, the constant increase for all Malmquist indices was around $40.0 \%$. The highest efficiency change was $13.1 \%$ in $2015 / 2016$, but in this period, technological change declined by $16.9 \%$, resulting in a decrease in total factor productivity change by $6.0 \%$. Meanwhile, the lowest efficiency change was $3.2 \%$ in $2012 / 2013$. Overall, efficiency change grew by $1.8 \%$, but technological change declined by $5.0 \%$ on average.

Table 12. Annual Malmquist Index Average with the Variable Operation Approach

\begin{tabular}{llllll}
\hline Periode & Effch & Techch & Pech & Sech & Tfpch \\
\hline $2011 / 2012$ & 0,976 & 1,043 & 0,980 & 0,996 & 1,018 \\
$2012 / 2013$ & 0,966 & 0,953 & 0,976 & 0,989 & 0,921 \\
$2013 / 2014$ & 1,047 & 0,870 & 1,042 & 1,005 & 0,912 \\
$2014 / 2015$ & 0,972 & 1,055 & 0,979 & 0,993 & 1,026 \\
$2015 / 2016$ & 1,131 & 0,831 & 1,063 & 1,064 & 0,940 \\
Rata-rata & $\mathbf{1 , 0 1 8}$ & $\mathbf{0 , 9 5 0}$ & $\mathbf{1 , 0 0 8}$ & $\mathbf{1 , 0 0 9}$ & $\mathbf{0 , 9 6 3}$ \\
\hline Notes: Technical efficiency & change (effch), technological change \\
(techch), pure efficiency change (pech), scale Efficiency change (sech), \\
total factor productivity change (tfpch)
\end{tabular}

The fluctuation of total factor productivity change in Figure 3 shows that the increase only happened in $2011 / 2012$ by $1.8 \%$ and in $2014 / 2015$ by $2.6 \%$. While in other periods, this value declined, i.e., $7.9 \%$ in $2012 / 2013,8.8 \%$ in $2013 / 2014$, and $6.0 \%$ in $2015 / 2016$. 
Jurnal Bisnis dan Manajemen, Volume 20, No. 2, September 2019, p. 145-174

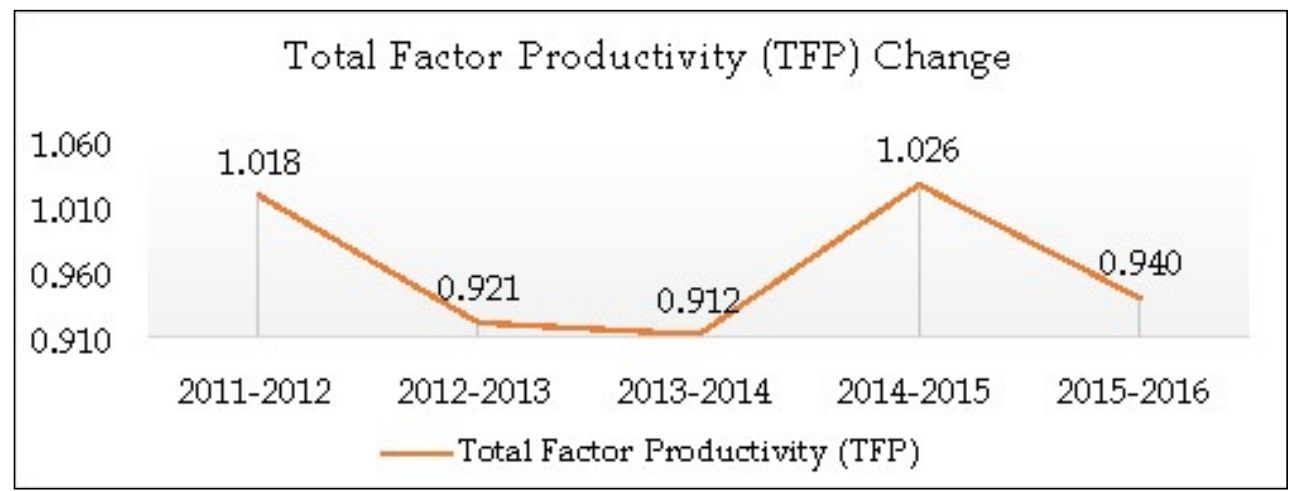

Figure 3. Total Factor Productivity Change with Operation Variable Approach

The average Malmquist index of IRDBs using the operation variable approach in table 13 shows that most IRDBs increased their productivity in almost all Malmquist indices, with the exception of the technological change and total factor productivity change index, decreasing by $5.3 \%$ and $3.5 \%$ respectively. Accordingly, $64.0 \%$ of IRDBs succeeded in achieving an increase in efficiency change, $32.0 \%$ of IRDBs decreased, and $4.0 \%$ did not change in the efficiency change index. Also, the results of the analysis show that $36.0 \%$ of IRDBs that have achieved an increase in total factor change productivity is supported by an increase in the efficiency change and scale efficiency change index.

Table 13. Average Malmquist Index IRDBs with Operation Variable Approach

\begin{tabular}{lllllll}
\hline No & IRDB & Effch & Techch & Pech & Sech & Tfpch \\
\hline 1 & A25 & 1,187 & 0,943 & 1,188 & 0,999 & 1,120 \\
2 & A03 & 1,151 & 0,931 & 1,044 & 1,103 & 1,072 \\
3 & A21 & 1,112 & 0,948 & 1,125 & 0,988 & 1,055 \\
4 & A06 & 1,000 & 1,045 & 1,000 & 1,000 & 1,045 \\
5 & A07 & 1,064 & 0,967 & 1,053 & 1,011 & 1,029 \\
6 & A13 & 1,030 & 0,997 & 1,025 & 1,005 & 1,026 \\
7 & A12 & 1,102 & 0,929 & 1,083 & 1,017 & 1,023 \\
8 & A04 & 1,053 & 0,959 & 1,033 & 1,019 & 1,010 \\
9 & A01 & 1,047 & 0,961 & 1,000 & 1,047 & 1,006 \\
10 & A10 & 1,040 & 0,959 & 1,000 & 1,040 & 0,998 \\
11 & A22 & 1,015 & 0,971 & 1,036 & 0,979 & 0,986 \\
12 & A16 & 1,017 & 0,968 & 1,023 & 0,994 & 0,984 \\
13 & A19 & 1,027 & 0,948 & 1,025 & 1,002 & 0,974 \\
14 & A14 & 1,109 & 0,869 & 0,954 & 1,163 & 0,964 \\
15 & A02 & 1,030 & 0,924 & 1,000 & 1,030 & 0,952 \\
16 & A09 & 0,977 & 0,967 & 0,941 & 1,039 & 0,945 \\
17 & A15 & 1,001 & 0,942 & 0,999 & 1,003 & 0,943 \\
18 & A11 & 1,044 & 0,902 & 0,985 & 1,060 & 0,942 \\
19 & A05 & 0,972 & 0,953 & 0,947 & 1,027 & 0,927
\end{tabular}

EFFICIENCY AND PRODUCTIVITY ANALYSIS OF INDONESIAN REGIONAL DEVELOPMENT BANKS: MULTI-STAGE DEA APPROACH AND MALMQUIST PRODUCTIVITY INDEX 
Jurnal Bisnis dan Manajemen, Volume 20, No. 2, September 2019, p. 145-174

\begin{tabular}{lllllll}
20 & A08 & 0,970 & 0,941 & 1,000 & 0,970 & 0,913 \\
21 & A18 & 0,925 & 0,978 & 0,932 & 0,992 & 0,905 \\
22 & A20 & 0,901 & 0,987 & 1,000 & 0,901 & 0,889 \\
23 & A17 & 0,893 & 0,974 & 0,959 & 0,931 & 0,870 \\
24 & A24 & 0,877 & 0,937 & 0,878 & 0,998 & 0,821 \\
25 & A23 & 0,942 & 0,783 & 1,000 & 0,942 & 0,738 \\
& Average & $\mathbf{1 , 0 1 9}$ & $\mathbf{0 , 9 4 7}$ & $\mathbf{1 , 0 0 9}$ & $\mathbf{1 , 0 1 0}$ & $\mathbf{0 , 9 6 5}$ \\
\hline
\end{tabular}

Notes: Technical efficiency change (effch), technological change (techch), pure efficiency change (pech), scale Efficiency change (sech), total factor productivity change (tfpch)

Table 14 shows that the average annual Malmquist in 2011-2016 increases in terms of technological change and it has been the primary factor for supporting the productivity increase of IRDBs in utilizing their assets. During the observation, the increase in technological change was $24.2 \%$. The highest score was in $2014 / 2015$, increasing by $35.8 \%$ after in the previous year $(2013 / 2014)$ decreased by $5.4 \%$.

Table 14. The annual average Malmquist Index with the Asset Variable Approach

\begin{tabular}{llllll}
\hline Period & Effch & Techch & Pech & Sech & Tfpch \\
\hline $2011 / 2012$ & 0,821 & 1,309 & 0,762 & 1,077 & 1,075 \\
$2012 / 2013$ & 0,893 & 1,300 & 1,281 & 0,697 & 1,160 \\
$2013 / 2014$ & 1,226 & 0,946 & 1,041 & 1,178 & 1,160 \\
$2014 / 2015$ & 0,821 & 1,358 & 0,904 & 0,908 & 1,115 \\
$2015 / 2016$ & 0,891 & 1,297 & 0,784 & 1,136 & 1,156 \\
Average & $\mathbf{0 , 9 3 0}$ & $\mathbf{1 , 2 4 2}$ & $\mathbf{0 , 9 5 4}$ & $\mathbf{0 , 9 9 9}$ & $\mathbf{1 , 1 3 3}$ \\
\hline
\end{tabular}

Notes: Technical efficiency change (effch), technological change (techch), pure efficiency change (pech), scale Efficiency change (sech), total factor productivity change (tfpch)

Efficiency change declined over time, except in $2013 / 2014$, increasing by $22.6 \%$. Pure technical efficiency and scale efficiency decreased by averagely $4.6 \%$ and $0.1 \%$. As a result of an increase in technological efficiency and efficiency change,
IRDBs were recorded to experience an increase in total factor productivity by averagely 13.3\%. Besides, the highest increase was in 2012/2013 and $2013 / 2014$, reaching $16.0 \%$, followed by $15.6 \%$ in the last two years. 
Jurnal Bisnis dan Manajemen, Volume 20, No. 2, September 2019, p. 145-174

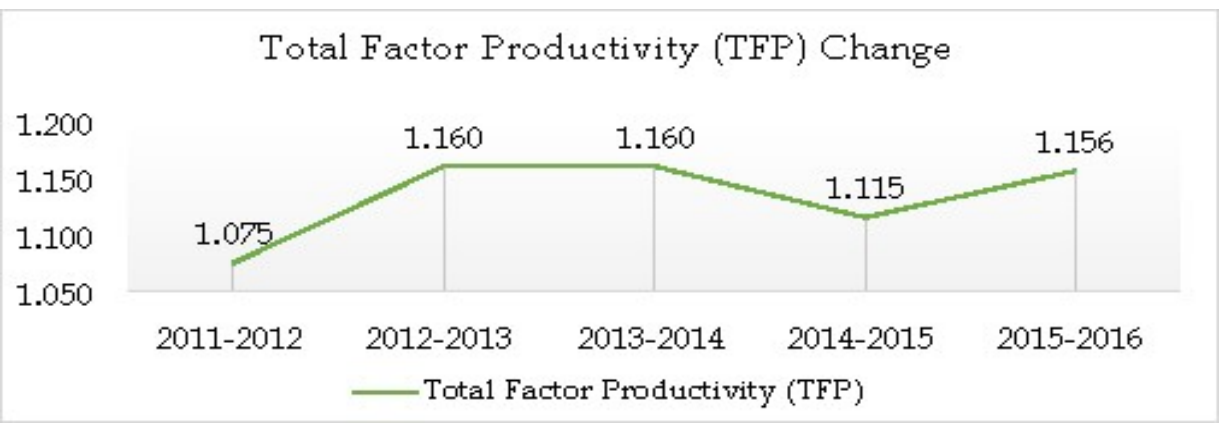

Figure 4. Total Factor Productivity Change with Asset Variable Approach

Table 15 shows that all IRDBs experienced an increase in the technological change index. Most of the IRDBs experiencing an increase in efficiency change and technological change were in the top position in terms of total factor productivity change, although they experienced a slight decrease in terms of scale efficiency. Around $84.0 \%$ of IRDBs successfully increased total factor productivity change in the six years of the observation period. Besides, the increase in total factor productivity change using asset variable approach, as revealed in Figure 4, shows that it has a better performance compared to the other two approaches in this research. 
Jurnal Bisnis dan Manajemen, Volume 20, No. 2, September 2019, p. 145-174

Table 15. Average Malmquist Index IRDB with Asset Variable Approach

\begin{tabular}{|c|c|c|c|c|c|c|}
\hline No & IRDB & Effch & Techch & Pech & Sech & Tfpch \\
\hline 1 & A03 & 1,131 & 1,279 & 1,149 & 0,984 & 1,446 \\
\hline 2 & A11 & 1,073 & 1,221 & 1,087 & 0,987 & 1,310 \\
\hline 3 & A20 & 1,009 & 1,292 & 0,913 & 1,105 & 1,304 \\
\hline 4 & A16 & 1,034 & 1,242 & 1,357 & 0,762 & 1,284 \\
\hline 5 & A17 & 1,182 & 1,085 & 1,000 & 1,182 & 1,283 \\
\hline 6 & A12 & 0,974 & 1,295 & 0,952 & 1,024 & 1,261 \\
\hline 7 & A10 & 0,987 & 1,275 & 0,990 & 0,997 & 1,259 \\
\hline 8 & A14 & 0,974 & 1,266 & 1,002 & 0,972 & 1,234 \\
\hline 9 & A25 & 0,946 & 1,302 & 0,952 & 0,993 & 1,231 \\
\hline 10 & A04 & 1,008 & 1,220 & 1,005 & 1,003 & 1,230 \\
\hline 11 & A01 & 1,000 & 1,021 & 1,000 & 1,000 & 1,201 \\
\hline 12 & A05 & 0,989 & 1,213 & 0,758 & 1,305 & 1,199 \\
\hline 13 & A18 & 0,948 & 1,234 & 1,039 & 0,912 & 1,169 \\
\hline 14 & A07 & 0,961 & 1,207 & 0,959 & 1,002 & 1,160 \\
\hline 15 & A06 & 0,945 & 1,213 & 0,945 & 1,001 & 1,147 \\
\hline 16 & A02 & 0,917 & 1,240 & 1,000 & 0,917 & 1,137 \\
\hline 17 & A24 & 0,890 & 1,275 & 0,927 & 0,960 & 1,135 \\
\hline 18 & A 15 & 0,850 & 1,314 & 0,884 & 0,962 & 1,117 \\
\hline 19 & A 21 & 0,859 & 1,215 & 0,841 & 1,022 & 1,044 \\
\hline 20 & A19 & 0,825 & 1,245 & 1,000 & 0,825 & 1,028 \\
\hline 21 & A23 & 0,835 & 1,204 & 0,884 & 0,999 & 1,006 \\
\hline 22 & A08 & 0,848 & 1,136 & 1,000 & 0,848 & 0,964 \\
\hline 23 & A09 & 0,794 & 1,199 & 0,809 & 0,981 & 0,952 \\
\hline 24 & A13 & 0,642 & 1,249 & 0,649 & 0,990 & 0,802 \\
\hline \multirow[t]{2}{*}{25} & A22 & 0,606 & 1,199 & 0,641 & 0,946 & 0,726 \\
\hline & Average & 0,929 & 1,226 & 0,950 & $\mathbf{0 , 9 8 7}$ & 1,145 \\
\hline
\end{tabular}

Notes: Technical efficiency change (effch), technological change (techch), pure efficiency change (pech), scale Efficiency change (sech), total factor productivity change (tfpch)

\section{CONCLUSION}

This research tests the efficiency and analyzes the productivity change of Indonesian Regional Development Banks (IRDBs) throughout Indonesia from 2011 until 2016, using a non-parametric approach of Data Envelopment Analysis (DEA). The analysis of the efficiency level of BPDs was conducted using three approaches, namely intermediation, operation, and the asset approach.
Multi-stage DEA was adopted to result in an efficiency score of each BPD. For data analysis, this research uses the assumption of an input-orientated variable return to scale (VRS). Malmquist Productivity Index (MPI) was utilized to measure the total factor productivity change (Tfpch), indicating the increase or decrease of performance of IRDBs from 2011-2016. 
Jurnal Bisnis dan Manajemen, Volume 20, No. 2, September 2019, p. 145-174

The analysis of Multi-stage DEA shows that; $28.0 \%$ of IRDBs were considered as the efficient frontier in the intermediation approach, $24.0 \%$ of IRDBs were considered efficient in operation approach, and only $8.0 \%$ of IRDBs were considered efficient in asset variable approach. These three approaches clarify that most of the IRDBs in Indonesia were not outstandingly efficient.

The analysis of Multi-stage DEA also shows that the IRDBs with the large core capital was consistently categorized as the BPDs with the highest average efficiency score (intermediation, operation, and asset approach). The results of this research support the idea that IRDBs should increase their capital for increasing firm efficiency.

The MPI analysis shows that the highest productivity increase was in the asset approach of $84.0 \%$, supported by the increase in efficiency change and technological change. While in intermediation and operation approach, the increase was only $44.0 \%$ and $36.0 \%$, depending on the increase in efficiency change and scale efficiency change.

MPI shows that the total factor productivity of the IRDBs with largest core capital consistently had the largest increase in the average score using the three approaches in this study. Thus, it is essential for the BPDs to have an effective capital strategy so they can improve themselves to be in BUKU 3 and BUKU 4.

\section{REFERENCES}

Afsharian, M., Ahn, H., \& Neumann, L. (2016). Generalized DEA: an approach for supporting input/output factor determination in DEA. Benchmarking, 23(7), 1892-1909. https://doi.org/10.1108/BIJ-07-2015-0074.

Avkiran, N. K. (1999). The evidence on efficiency gains: The role of mergers and the benefits to the public. Journal of Banking and Finance, 23(7), 991-1013. https://doi.org/10.1016/S0378-4266(98)00129-0.

Banker, R. D., Charnes, A., \& Cooper, W. W. (1984). Some Models for Estimating Technical and Scale Inefficiencies in Data Envelopment Analysis. Management Science, 30.

Bauer, P. W., Berger, A. N., Ferrier, G. D., \& Humphrey, D. B. (1998). Consistency conditions for regulatory analysis of financial institutions: A comparison of frontier efficiency methods. Journal of Economics and Business, 50(2), 85-114.

Berger, A. N., \& Humphrey, D. B. (1997). Efficiency of financial institutions: International survey and directions for future research. European Journal of Operational Research, 98(2), 175-212. https://doi.org/10.1016/S0377-2217(96)00342-6.

Berger, A. N., \& Humphrey, D. B. (1992). Measurement and efficiency issues in commercial banking. In Output Measurement in the Service Sectors.

Casu, B., \& Molyneux, P. (2003). A comparative study of efficiency in European banking. Applied Economics, 35(17), 1865-1876. https://doi.org/10.1080/0003684032000158109,

Charnes, A., Cooper, W. W., Lewin, A. Y., \& Seiford, L. M. (Eds.). (2013). Data envelopment analysis: Theory, methodology, and applications. Springer Science \& Business Media.

Charnes, A., Cooper, W. W., \& Rhodes, E. (1978). Measuring the efficiency of decision making units. European Journal of Operational Research, 2(6), 429-444. https://doi.org/10.1016/03772217(78)90138-8.

Chansarn, S. (2008). The Relative Efficiency of Commercial Banks in Thailand: DEA Approach. Bangkok University.

Depren, S. K., \& Depren, O. (2016). Measuring efficiency and total factor productivity using data envelopment analysis: An empirical study from banks of Turkey. International Journal of Economics and Financial Issues, 6(2), 711-717.

Douglas W . Caves, Laurits R . Christensen, W. . E. D. (2012). The Economic Theory of Index Numbers 
Jurnal Bisnis dan Manajemen, Volume 20, No. 2, September 2019, p. 145-174

and the Measurement of Input, Output, and Productivity Author ( $\mathrm{s}$ ): Douglas W . Caves , Laurits R . Christensen, W . Erwin Diewert Reviewed work ( $\mathrm{s}$ ): Published by: The Econometric Society Stable URL: http://www. Economic Theory, 50(6), 1393-1414.

Emrouznejad, A., \& Yang, G. liang. (2018). A survey and analysis of the first 40 years of scholarly literature in DEA: 1978-2016. Socio-Economic Planning Sciences, 61, 4-8. https://doi.org/10.1016/j.seps.2017.01.008.

Färe, R., Grosskopf, S., Norris, M., \& Zhang, Z. (1994). Productivity Growth, Technical Progress, and Efficiency Change in Industrialized Countries. The American Economic Review, 84(1), 66-83. Retrieved from http://www.jstor.org/stable/2117971.

Färe, R., \& Grosskopf, S. (1992). Malmquist Productivity Indexes and Fisher Ideal Indexes. Society, 102(410), $158-160$.

Farrel, M. J. (1957). The Measurement of Productive Efficiency. Journal of the Royal Statistical Society, 120(3), 253-290.

Ferdian, I. R., \& Purwantoro, R. N. (2006). Pengukuran Kinerja Bank Syariah: Integrasi Pendekatan DEA dengan Analisis Rasio Keuangan. Usahawan No. 10 TH XXXV Oktober.

Fethi, M. D., \& Pasiouras, F. (2010). Assessing bank efficiency and performance with operational research and artificial intelligence techniques: A survey. European Journal of Operational Research, 204(2), 189-198. https://doi.org/10.1016/j.ejor.2009.08.003

Grifell-Tatjé, E., \& Lovell, C. A. K. (1996). Deregulation and productivity decline: The case of Spanish savings banks. European Economic Review, 40(6), 1281-1303. https://doi.org/10.1016/00142921(95)00024-0

Gunawan, F. A., \& Utiyati, S. (2013). Analisis Tingkat Efisiensi Bank BUMN Dengan Pendekatan Data Envelopment Analysis (DEA). Jurnal Ilmu \& Riset Manajemen, 2(8), 1-17.

Hadad, M. D., Santoso, W., Ilyas, D., \& Mardanugraha, E. (2003). Analisis efisiensi industri perbankan Indonesia: Penggunaan metode nonparametrik data envelopment analysis (DEA). Research Paper, 7(5), 1-28.

Jemric, I., \& Vujcic, B. (2002). Efficiency of Banks in Croatia: A DEA Approach. Comparative Economic
Studies, 44(2-3), https://doi.org/10.1057/ces.2002.13.

Malmquist, S. (1953). Index numbers and indifference surfaces. Trabajos de Estadistica y de Investigacion Operativa, 4(2), 209-242.

Nishimizu, M., \& Page, J. M. (1982). Total Factor Productivity Growth, Technological Progress and Technical Efficiency Change: Dimensions of Productivity Change in Yugoslavia, 1965-78. The Economic Journal, 92(368), 920. https://doi.org/10.2307/2232675.

Saeed, Ali, Adeeb, \& Hamid. (2013). Examining Efficiency of Islamic and Conventional Banks in Pakistan: Using Data Envelopment Analysis. Global Journal of Management and Business Research Finance, 13(10).

Sealey, C. W., \& Lindley, J. T. (1977). Inputs, Outputs, and a Theory of Production and Cost At Depository Financial Institutions. The Journal of Finance, 32(4), 1251-1266. https://doi.org/10.1111/j.15406261.1977.tb03324.x.

Sufian, F. (2007). Malmquist Indices of Productivity Change in Malaysian Islamic Banking Industry: Foreign Versus Domestic Banks. Journal of Economic Cooperation, 1, 115-150.

Wahidudin, A.N. (2010), "Technical Efficiency of Commercial Banks in Malaysia: An Application of Window Data Envelopment Analysis", Munich Personal RePEc Archive (MPRA) Paper, Vol. 16 No. 45136, pp. 1-12.

Wijatmoko, B. (2011), “Analisis Efisiensi Teknis Industri Bank Pembangunan Daerah (BPD) Di Indonesia Menggunakan Metode Data Envelopment Analysis (DEA) Tahun 2007-2009”, Unpublished Thesis, Retrieved from http://www.perpustakaan.uns.ac.id on December 20th, 2017.

Worthington, A. C. (1999). Malmquist indices of productivity change in Australian financial services. Journal of International Financial Markets, 9(1), 303-320. https://doi.org/https://doi.org/10.1016/S10424431(99)00013-X 